OPEN ACCESS

Edited by:

Maria Beatrice Bilo,

Azienda Ospedaliero Universitaria

Ospedali Riuniti, Italy

Reviewed by:

Peter Korosec

University Clinic of Pulmonary and Allergic Diseases Golnik, Slovenia

Gunter Sturm,

Medical University of Graz, Austria

*Correspondence:

Umit Murat Sahiner umsahner@yahoo.com

Specialty section:

This article was submitted to Molecular Innate Immunity,

a section of the journal

Frontiers in Immunology

Received: 21 January 2019 Accepted: 02 August 2019

Published: 21 August 2019

Citation:

Sahiner UM and Durham SR (2019) Hymenoptera Venom Allergy: How Does Venom Immunotherapy Prevent Anaphylaxis From Bee and Wasp Stings? Front. Immunol. 10:1959. doi: 10.3389/fimmu.2019.01959

\section{Hymenoptera Venom Allergy: How Does Venom Immunotherapy Prevent Anaphylaxis From Bee and Wasp Stings?}

\author{
Umit Murat Sahiner ${ }^{1,2 \star}$ and Stephen R. Durham ${ }^{1,3}$ \\ 1 Immunomodulation and Tolerance Group, Allergy and Clinical Immunology Inflammation, Repair and Development, National \\ Heart and Lung Institute, Imperial College London, London, United Kingdom, ${ }^{2}$ Pediatric Allergy Department, Hacettepe \\ University School of Medicine, Ankara, Turkey, ${ }^{3}$ MRC and Asthma UK Centre in Allergic Mechanisms of Asthma, London, \\ United Kingdom
}

Hymenoptera stings may cause both local and systemic allergic reactions and even life threatening anaphylaxis. Along with pharmaceutical drugs and foods, hymenoptera venom is one of the most common causes of anaphylaxis in humans. To date, no parameter has been identified that may predict which sensitized people will have a future systemic sting reaction (SSR), however some risk factors, such as mastocytosis and age $>40$ years are known. Venom immunotherapy (VIT) is the most effective method of treatment for people who had SSR, which is shown to be effective even after discontinuation of the therapy. Development of peripheral tolerance is the main mechanism during immunotherapy. It is mediated by the production of blocking lgG/lgG4 antibodies that may inhibit IgE dependent reactions through both high affinity (Fc\&RI) and low affinity (Fc\&RII) IgE receptors on mast cells, basophils and B cells. The generation of antigen specific regulatory $T$ cells produces $\mathrm{IL}-10$ and suppresses Th2 immunity and the immune responses shift toward a Th1-type response. B regulatory cells are also involved in the production of IL-10 and the development of long term immune tolerance. During VIT the number of effector cells in target organs also decreases, such as mast cells, basophils, innate type 2 lymphocytes and eosinophils. Several meta-analyses and randomized controlled studies have proved that VIT is effective for preventing SSR to a sting and improves the quality of life. In this review, the risk of SSR in venom allergy and how VIT changed this risk are discussed.

\section{Keywords: allergy, anaphylaxis, venom, immunotherapy, immune tolerance}

\section{INTRODUCTION}

The Hymenoptera insect group includes Apidae and Vespidae subgroups and also the Formicidae, which is beyond the scope of this review. Apidae consists of Apis mellifera (honey bees) and Bumblebee species (bumblebees), and the Vespidae subclass includes Vespula species ("yellow jackets," wasps and hornets) and Polistes species ("paper" wasps) $(1,2)$. Honeybee stings are generally not more severe but they inject more venom. Bees inject 50-140 micrograms of venom whereas wasps deliver nearly $3 \mu \mathrm{g}$ of venom with each sting. Bees can sting once but wasps have the capacity to sting multiple times (1-3). Insect sting allergy may cause local, large local $(>10 \mathrm{~cm}$ in 
diameter) or even systemic reactions (SR), and potentially life threatening anaphylactic reactions (4-6). The rate of systemic sting reactions in epidemiological studies in Europe ranged between 0.3 and $7.5 \%$ in adults (7) and $0.15-3.4 \%$ in children $(7,8)$. The chance of a SR and the chance of life threatening anaphylaxis are related to many factors, including the severity of the preceding reaction, allergy to bee venom, the level of baseline serum tryptase and presence of mastocytosis, increased basophil activation, age and underlying medical conditions (7).

Venom immunotherapy (VIT) leads to complete protection from SSR in $77-84 \%$ of cases for honeybee and $91-96 \%$ for vespid venoms (9-11). The frequency of systemic adverse events during VIT ranges between 8 and 20\% from large multicenter studies $(12,13)$. In a recent study by Stoevesandt et al. a systemic reaction rate of $11.7 \%$ (any reactions including the subjective ones) was reported during build-up phase of VIT; however the SSR rate dropped to $3 \%$ when objective diagnostic criteria of anaphylaxis was used (14). The most important risk factors related to systemic reactions during VIT are honeybee venom immunotherapy, rapid dose increase during the build-up phase and probably high basal tryptase levels in vespid allergy but not in honeybee venom allergy (9). The protective effect of VIT persists for years after stopping treatment. The long term outcome of systemic reactions after discontinuation of VIT is superior in children compared to adults and for vespid venom compared to honeybee VIT (15-17).

This review aims to discuss first the epidemiology and risk factors of insect venom anaphylaxis, then focuses on the mechanisms of VIT to prevent SSR to insect stings and finally aims to discuss the efficacy, safety and long term effects of VIT as well as the risk factors related to SSR during and after VIT.

\section{EPIDEMIOLOGY OF VENOM ALLERGY AND ALLERGIC REACTIONS}

The prevalence of being stung by Hymenoptera species during life ranges from 56.6 to $94.5 \%$ in adults and $37.5 \%$ in children up to 14 years of age $(7,8)$. The sensitization rate, indicated either by a positive skin prick test or by specific IgE positivity, ranges between 9.3 and $28.7 \%$ in adults. In one study children were found to be $3.7 \%$ positive to Hymenoptera species (mostly honeybee) by skin prick testing (18).

The rate of systemic sting reactions in epidemiological studies in Europe ranges between 0.3 and $7.5 \%$ in adults (7). Among these reactions, the anaphylactic shock frequency is between 0.6 and $42.8 \%(18-23)$. According to a recent position paper in adults, respiratory and cardiovascular symptoms may occur in as many as $70 \%$ of the systemic reactions (24). This wide range reflects the lack of consensus on the definition of anaphylaxis, differences in data collection techniques and variability in degree of exposure to stings in different climate conditions (7). In children, the prevalence of SR is much lower and ranges from 0.15 to $3.4 \%(7,8)$. Additionally, of the SR in children about $60 \%$ are mild and restricted only to the skin (24).

Beekeepers are a vulnerable and high risk population for the development of allergic reactions to honeybee stings. In this specific group, the SR rates are higher than the general population and range from 14 to $38 \%$ (25). Receiving more than 200 stings per year is nearly totally protective from a SR whereas receiving fewer than 25 stings per year is related to a SR rate of $45 \%$ (25). In a British beekeeper survey, risk factors for SR were found to be female gender, positive family history of bee venom allergy, premedication with antihistamines before hive attendance and 2 or more years of beekeeping before the first SR (26).

According to the European network of severe allergic reactions (NORA), $20.2 \%$ of all the anaphylaxis cases in children and $48.2 \%$ of documented anaphylaxis in adults were due to insect venom. In this study, 59 tertiary allergy, dermatology and pediatrics centers from 10 different countries reported 3,333 anaphylaxis cases (27). Only $27.6 \%$ of insect anaphylaxis cases received on-site adrenaline (27). In population based studies performed during the first decade of the twenty-first century, the rate of anaphylaxis due to insect venom ranged from 7.3 to $59 \%$ and was found mostly in adults (7).

Fatalities from insect stings have been examined previously in a number of studies. A study from Costa Rica reported 52 deaths in a 22 years period accounting to 0.74 deaths per million inhabitants per year (28), which is much higher than a study from the USA with a number of 0.14 deaths per million inhabitants per year (29). A recent report from the UK stated 93 deaths from venom anaphylaxis between 1992 and 2012, accounting to 0.09 deaths per million inhabitants per year (30). Especially a previous history of hymenoptera allergy, male sex, older age and delayed adrenaline administration are important risk factors for fatal reactions $(31,32)$.

Risk factors related to SSR to hymenoptera stings are summarized in Table $\mathbf{1 .}$

\section{VENOM ALLERGY, MAST CELL ACTIVATION DISORDERS AND ANAPHYLAXIS}

Mastocytosis is a clonal neoplastic disorder of mast cells that is characterized primarily by cutaneous or systemic subtypes and sometimes by rare forms. Mastocytosis usually involves the somatic KIT D816V mutation, shows aberrant CD25 or $\mathrm{CD} 2$ expression on mast cells and is frequently accompanied by elevated baseline serum tryptase (BST) (40). In patients with cutaneous mastocytosis, mast cell aggregates are located only in the skin and this form is mostly diagnosed in infants and children (41). Systemic mastocytosis (SM) is frequently found in adults and is divided into four subtypes (indolent SM, SM associated with a hematological disorder, aggressive SM and mast cell sarcoma); the most common among these is indolent systemic mastocytosis (ISM). ISM can present with normal BST and lack of skin lesions (42). The prevalence of mastocytosis in patients with hymenoptera venom allergy may be as high as $7.9 \%$, which is significantly higher than that of the general population (3-13/100,000 inhabitants) (43, 44). Similarly, hymenoptera stings are the most common cause of anaphylaxis in people with mastocytosis, and the prevalence is nearly $30 \%$ (45). In a considerable number of 
TABLE 1 | Risk factors for severe systemic reactions/anaphylaxis to hymenoptera stings.

\begin{tabular}{|c|c|}
\hline Risk factor & Characteristics \\
\hline Age around >40 years $(33,34)$ & $\begin{array}{l}\text { Milder reactions in children, higher risk in } \\
\text { adults especially age over } 40 \text { years }\end{array}$ \\
\hline $\begin{array}{l}\text { Elevated basal serum tryptase } \\
(34,35)\end{array}$ & $\begin{array}{l}\text { In patients even without mastocytosis } \\
\text { there is an increased risk of severe } \\
\text { systemic reactions }\end{array}$ \\
\hline Mastocytosis (35-37) & $\begin{array}{l}\text { Especially in adult patients with } \\
\text { mastocytosis and in indolent mastocytosis } \\
\text { without skin lesions }\end{array}$ \\
\hline $\begin{array}{l}\text { Absence of skin smptoms during } \\
\text { anaphylaxis }(34,38)\end{array}$ & $\begin{array}{l}\text { Lack of urticaria and angioedema may be } \\
\text { related to the indolent systemic } \\
\text { mastocytosis without skin lesions }\end{array}$ \\
\hline $\begin{array}{l}\text { Short time interval between sting } \\
\text { and onset of symptoms }(34,38)\end{array}$ & $\begin{array}{l}\text { If symptoms start in }<5 \text { min, risk of severe } \\
\text { systemic reaction increases }\end{array}$ \\
\hline Severity of the previous reaction (7) & $\begin{array}{l}\text { The more severe the previous reaction, the } \\
\text { greater the risk of a future severe reaction }\end{array}$ \\
\hline $\begin{array}{l}\text { Angiotensin converting enzyme } \\
\text { inhibitor and } \beta \text {-blockers usage } \\
\text { (Cardiac comorbidities) }(14,39)\end{array}$ & $\begin{array}{l}\text { Debated. May increase the reaction } \\
\text { severity not the reaction risk }\end{array}$ \\
\hline
\end{tabular}

patients with ISM, hymenoptera venom anaphylaxis (HVA) may be the first symptom of the disease. These ISM patients without skin lesions are mostly males with lower BST levels and lower frequency of KIT mutations (46). Anaphylaxis in patients with mastocytosis is mostly characterized by cardiac symptoms, such as hypotension and syncopal episodes, whereas skin symptoms, such as urticaria and angioedema are rare. Therefore, if a patient with VHA presents with hypotension and syncope without skin symptoms, mastocytosis should be suspected (47). Recently, for the cases of HVA, a scoring system called REMA was developed based on gender, clinical symptoms and BST to identify patients having clonal mast cell systemic disease. A score of $\geq 2$ suggests that ISM should be ruled out with a sensitivity and specificity of 92 and $81 \%$, respectively (47).

The precise mechanisms for the increased prevelance of HVA in mastocytosis are not well-understood. However, possible explanations for this co-existence are as follows: (1) Increased mast cell burden may lead to higher mediator release in the case of a sting; (2) The perivascular location of the mast cells may cause a direct access of mediators to the systemic circulation, which increase the severity of the reaction; (3) A gain of function mutation, KIT D816V, may prevent mast cell apoptosis and increases the proliferation and differentiation of the mast cells, and finally (4) Phospholipase A2, a component of hymenoptera venom may cause a direct mediator release from mast cells (36).

VIT seems to be the most appropriate treatment option for patients with mastocytosis and HVA. VIT is usually welltolerated, safe and effective. Whether BST increases the risk of adverse events during VIT is not yet clear. Despite the preference for lifelong VIT in patients with mastocytosis, there is no evidence based proof of lifelong treatment in the literature. However, to be on the safe side it is recommended that VIT should be prolonged in patients with elevated SBT
(>11.4 $\mu \mathrm{g} / \mathrm{L}$ ) or verified mastocytosis if the initial SSR was severe (9).

\section{MECHANISMS OF VENOM IMMUNOTHERAPY}

VIT is the only effective and immune modulatory treatment in patients with a history of anaphylaxis and has proven to be effective for between 80 and 95\% of patients with bee venom and vespula venom allergy, respectively (9-11). Initially, the interaction between allergens, epithelial cells and dendritic cells triggers the response produced by the innate immune system and subsequently the adaptive immune responses develop. Different parts of the immune system are involved in the development of peripheral immune tolerance, and in a network of different cell types, either directly through cell to cell contact or through release of various cytokines and specific antibody production (IgE, IgG1, IgG4, IgA). Further details of VIT mechanisms are shown in Figure 1.

\section{Allergen Specific Antibody Responses}

Initially subcutaneous VIT is associated with transient early increases in serum allergen specific $\operatorname{IgE}$ (sIgE) levels and then there is a decrease in sIgE over several years (48-50). AIT is also associated with increases in allergen-specific IgA, IgG1 and IgG4 antibodies, which are called blocking antibodies $(48,51)$. Studies with aeroallergens have shown significant increases in serum concentrations of blocking antibodies, up to 100 times in a time and dose dependent manner (52-54). The production of blocking antibodies, particularly the IgG4 type, can compete with sIgE for allergen and prevent the allergen-sIgE interaction. The blockage of allergen-sIgE interactions prevents cross-linking of high-affinity IgE receptors (FceRI) on basophils and mast cells, which inhibits degranulation of these cells and may prevent the development of anaphylaxis $(55,56)$. Blocking antibodies, IgG/IgG4, inhibit the IgE-facilitated allergen presentation to $\mathrm{T}$ cells by blocking low-affinity receptors (FcgRIIb) on B cells and stop the allergen induced boost of memory IgE production $(54,57,58)$. One of the major cytokines produced by T regs, IL10 , not only is involved in the suppression of allergen-specific $\mathrm{T}$ effector cells during AIT, but it also inhibits the production of total IgE and specific IgE, while increasing $\operatorname{IgG} 4$ levels $(59,60)$. In non-allergic beekeepers, the IgG4 serum concentrations are nearly one thousand times higher than the serum specific IgE levels. The serum IgG4 concentrations are closely correlated with the number stings per year and time spent in beekeeping $(31,61)$. In an animal model of bee venom allergy, major bee venom allergen PLA2 was injected into inguinal lymph nodes and an allergen-specific IgG response with the production of IgG2a was observed (62). In another study of peptide VIT, a reduction in allergen-specific IgE and an increase in specific IgG2a were found, both of which had preventive functions against allergeninduced anaphylaxis (63).

After stopping AIT for grass pollen allergy, it was shown that blocking IgG/IgG4 levels decreased nearly $80-90 \%$ 


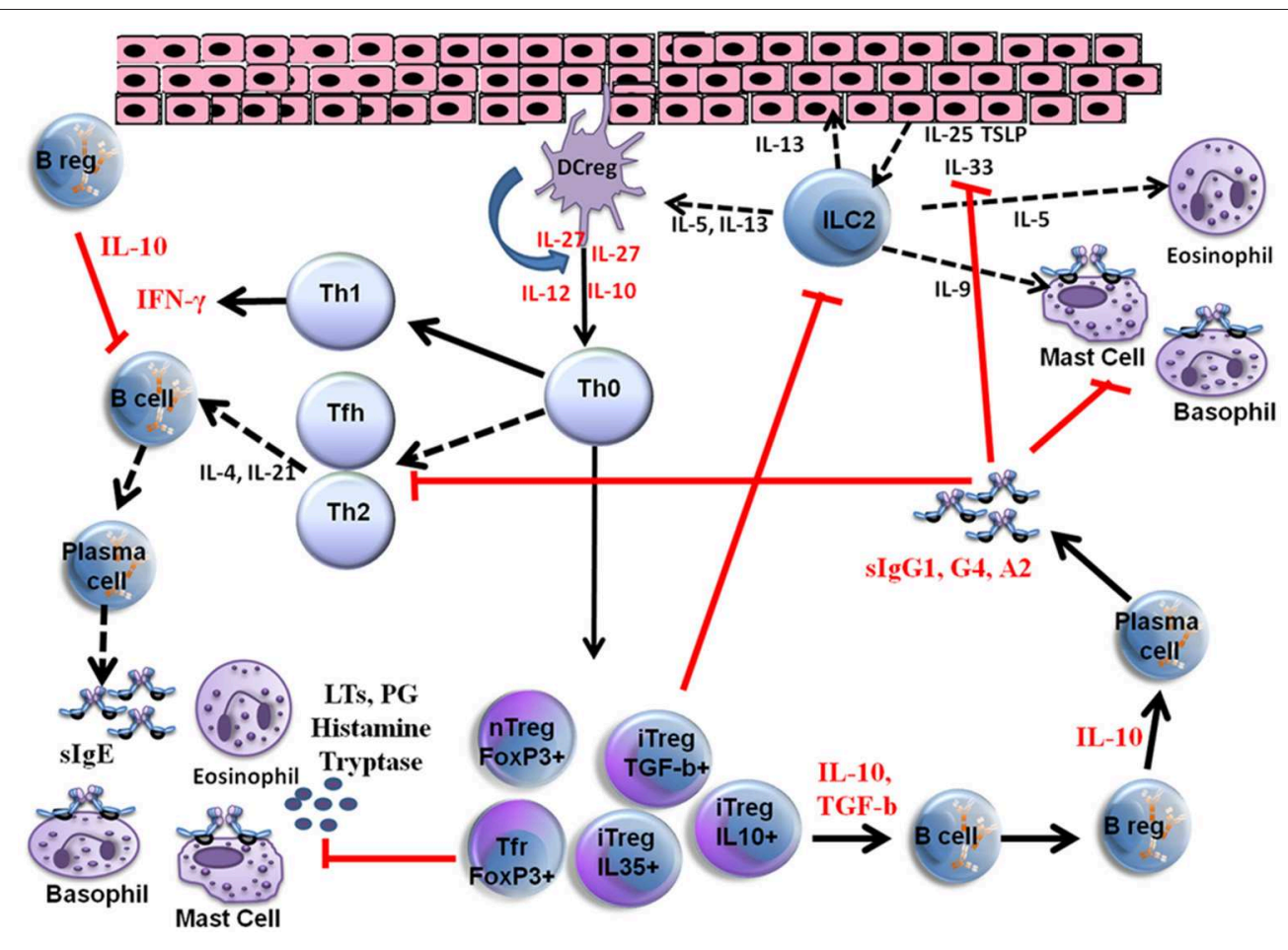

FIGURE 1 | Mechanisms of venom allergen immunotherapy. High dose of hymenoptera venom stimulates dendritic cells and induces Treg and B reg cells as well as other B cell subsets that produce allergen specific $\lg G 1$, IgG4, and IgA type bloking antibodies. Several cytokines also take place in the immune tolerance induction and as a result a shift from Th2 to Th1 type immune deviation occurs. Red arrows show blocking activity induced during VIT. LTs, Leukotrienes; PG, Prostaglandins; iTreg, Inducible Tregulatory cells; nTreg, Natural T regulatory cells; Tfh, T follicular hepler cells; Tfr, T Follicular regulatory cells; DC reg, Regulatory dendritic cells; TSLP, Thymic stromal Lymphopoietin.

within 1 year. In contrast, IgG-associated serum IgEinhibitory activity persisted for several years and correlated with clinical efficacy (64). This suggests that the functional activity of blocking antibodies rather than their levels may be a more accurate measure of clinical efficacy and seems to correlate closely with long term immune tolarance (54). However, this may not be the case for bee venom immunotherapy, where although successful desensitization was accompanied by increases in both IgG4 and IgEInhibitory activity, both the elevated specific IgG4 levels and IgE-FAB inhibitory activity returned to baseline within months of discontinuation of VIT and further follow up revealed a more sustained decrease in venom-specific $\operatorname{IgE}$ levels (65) representing a putative alternative mechanism of prolonged protection following IgG withdrawal. This is also supported by the observation of low/absent IgE levels in tolerant beekeepers (66).

\section{Effector Cell Responses}

VIT shows its action through complex immunological mechanisms. The initial mechanism of action seen on effector cells is mast cell and basophil desensitization (9). The number of these cells decreases during venom immunotherapy and additionally their thresholds for cytokine release increase with time. During the rush VIT early in the course of treatment there is a decrease in peripheral blood basophil numbers and also in the production and release of basophil derived cytokines, such as IL-4 and IL-13 (67). Basal serum tryptase level, which is a marker of mast cell burden and mast cell function, decreases over time during VIT (68). In patients with VIT, the suppression of surface antigens on blood basophils was shown previously (69). In addition to the changes observed in basophil surface antigens, the amount of histamine released from basophils following sting challenges also decreased in patients with VIT depending on their clinical reactivity (70). Basophil reactivity assessed in the flow-cytometric evaluation of CD63 expression has been shown to be a reliable diagnostic test to diagnose hymenoptera venom allergy (71). Basophil sensitivity, the dose at which half of the maximum basophil response occurs, was suggested to monitor VIT (72-74). A new method of functional assay that measures intracellular staining of phycoerythrin-conjugated daimine oxidase (DAO) has been validated for detecting the amount of histamine released from basophils. Following allergen stimulation, intracellular DAO levels decrease in proportion to the intracellular histamine released. This reduction was shown in patients treated with vespula VIT, which is important for increasing the threshold for venom to induce an anaphylactic reaction in VIT patients (75). Not only the preformed mediator release but also the production and release of newly generated mediators, such as 
leukotriene $\mathrm{C} 4$ in blood basophils in patients following VIT decreases (76).

Following rush VIT a decrease in T-cell expressed and secreted (RANTES) protein, IL-8 and monocyte chemoattractant protein 1 (MCP-1) production have been reported in peripheral blood mononuclear cell (PBMC) cultures at protein and as well as mRNA levels (77).

During the early phases of VIT the mechanisms that start desensitization are not fully understood. In 2010 Bussmann et al. performed a study on patients with rush VIT. They analyzed expression levels of different tolerogenic markers at protein and mRNA levels within the first 5 days of VIT. They observed a prominent degradation of tryptophan, which is linked to the suppression of $\mathrm{T}$ cell responses and induction of tolerance; elevated ILT3 and ILT4, which are inhibitory receptors for monocytes, and IL-10 production of $\mathrm{CD}^{+}{ }^{+} \mathrm{T}$ cells and monocytes followed by increased IL-10 serum levels, which is an important regulatory interleukin for the suppression of allergen induced responses (78).

In studies with aeroallergens, AIT was shown to inhibit early and late phase allergic responses at allergic tissue sites through the suppression of several cytokines and decreases in numbers of eosinophils, mast cells and basophils (54). This information indicates that allergen immunotherapy is effective at both systemic and local levels. Similar mechanisms are likely to apply to VIT.

\section{T and B Cell Responses During VIT}

The development of immune tolerance during VIT has been shown to be related to the modification of $\mathrm{T}$ and $\mathrm{B}$ cell responses (79). A Th2 to Th1 shift occurs during VIT and an increase in interferon gamma (IFN- $\gamma$ ) levels is observed parallel to the decrease in IL-4 and IL-13 in whole blood $(80,81)$. Th2 responses during VIT are reduced and there is also an increase in Treg cell numbers and functions $(80,82)$. Treg cells are divided into 2 subgroups as natural regulatory $\mathrm{T}$ (nTreg) cells, which are characterized by the transcription factor forkhead box P3 (FOXP3), and inducible regulatory T (iTreg) cells, such as IL-10 producing Tr1 cells and TGF-b producing TH3 cells (83-85). IL-10 plays an inhibitory role in B cells by blocking B7/CD28 pathway. This results in a supressive effect on dendritic cell maturation and in MHC class II and costimulatory ligand expressions (86). TGF-b downregulates FceRI expression on Langerhans cells and also upregulates FOXP3 and RUNX and assists CTLA-4 expression on T cells $(87,88)$.

In beekeepers IL-10 producing Treg cells inhibit the proliferation of PLA-specific effector $\mathrm{T}$ cells shortly after the start of bee venom season. This suppressive effect can be reversed by blocking CTLA-4, PD-1, and IL-10 receptors (89). Additionally induction of indoleamine 2,3-dioxygenase enzyme in dendritic cells, by the effect of Tregs, causes the transformation of inflammatory dendritic cells into regulatory dendritic cells (90). In a similar manner, during VIT, Trl-type Treg cell proliferation is prominent and the antigen-specific proliferative and cytokine responses against the major bee venom allergen, the phospholipase A2 (PLA) have been significantly suppressed by the end of first week of VIT (91). The allergen induced secretion of Th2 cytokines, such as IL-4, IL-5, and IL-13 were abolished (92). In addition to IL-10 production, Treg cells can also suppress immune responses via cell-to-cell interactions.

The role of increased IL-10 levels is prominent in the development of clinical and immunological tolerance during VIT. Blockage of IL-10 in PBMC reconstitutes the specific proliferative and cytokine responses. This situation can also be seen in beekeepers who have received multiple bee stings (91). The presence of increased numbers of $\mathrm{CD} 4^{+} \mathrm{CD} 25^{+} \mathrm{FOXP} 3^{+}$ Treg cells in the target organ, nasal mucosa, after grass pollen allergen immunotherapy suggests that Treg cells play an important for the development of allergen-specific immune tolerance (93). In a similar manner, VIT was found to be related to the progressive expansion of circulating $\mathrm{CD}^{+}{ }^{+} \mathrm{CD} 25^{+} \mathrm{FOXP}^{+}$Treg cell numbers (94). During all types of AIT a deviation toward a regulatory/suppressor $\mathrm{T}$ cell response has been reported (95). In a study by Nasser et al allergen-induced changes in cytokine mRNA and cellular profiles from cutaneous biopsies were compared before and 3 months after wasp VIT. There was a significant decrease in IL-4 mRNA and an increase in IL- $10^{+}$cells. Additionally a trend toward an increase in IL-10 mRNA was also observed (96). In another study by Schuerwegh et al, the effect of VIT on $\mathrm{CD}^{+} \mathrm{CD}^{+} \mathrm{T}$ lymphocytes were evaluated before VIT, at the end of 5 days semi-rush VIT and at 6 months during VIT. A significant decrease in IL-producing $\mathrm{CD}^{+}$and $\mathrm{CD} 8^{+} \mathrm{T}$ cell numbers, compared with cytokine-producing cells before VIT was observed by the end of 5 days semi-rush VIT. After 6 months of VIT, a higher amount of IL-2 and IFN- $\gamma$-producing $\mathrm{CD} 4^{+} \mathrm{CD} 8^{+} \mathrm{T}$ lymphocytes has been found confirming a shift from Th2 to Th1 type immune deviation (81). IL-10 serum levels began to increase from the second day of VIT (78) and on day 28 of treatment, a desensitized condition has arisen in allergen-specific $\mathrm{T}$ cells associated with the direct suppressive effects of IL-10 (94).

$\mathrm{T}$ follicular helper cells $\left(\mathrm{T}_{\mathrm{FH}}\right)$ are defined by $\mathrm{CXCR} 5^{+}$ surface receptor and they help for B-cell maturation and immunoglobulin class-switching. CXCR5 ${ }^{+}$FoxP3 $^{+}$Treg cells are a subset of Tregs, called as follicular regulatory $\mathrm{T}\left(\mathrm{T}_{\mathrm{FR}}\right)$ cells, which are capable of suppressing $\mathrm{T}$ - and B-cell responses by migrating to germinal centers of lymph nodes $(97,98)$. A study by grass pollen immunotherapy has shown a significant decrease in memory $\mathrm{T}_{\mathrm{FH}}$ cell numbers after immunotherapy (99). Additionally, $\mathrm{T}_{\mathrm{FR}}$ cells were found to produce more IL10 compared to $\mathrm{T}_{\mathrm{FH}}$ cells. The plasticity between $\mathrm{T}_{\mathrm{FH}}$ and $\mathrm{T}_{\mathrm{FR}}$ cells have been shown in the same study suggesting that $\mathrm{T}_{\mathrm{FR}}$ cells may play important roles in suppressing $\mathrm{TH} 2$ responses and allergen specific IgE production during immunotherapy (99). It is likely that similar $\mathrm{T}_{\mathrm{FR}}$ and $\mathrm{T}_{\mathrm{FH}}$ cell mechanisms are present during venom imunotherapy as in grass pollen immunotherapy.

Recently IL-10-secreting allergen-specific Breg cells have been identified in bee venom tolerant beekeepers and VIT administered patients (100). Breg cells are characterized as $\mathrm{CD}_{3} 3^{-} \mathrm{CD} 25^{+} \mathrm{CD} 71^{+} \mathrm{B}$ cells, which are capable of suppressing bee venom specific $\mathrm{CD} 4^{+} \mathrm{T}$ cells and capable of producing allergen-specific IgG4 antibodies after bee VIT 
(100). Additionally, Breg cells can also show their inhibitory capacity by producing IL-35 and TGF-beta (101). Apart from Treg and B reg cells, IL-10-secreting natural killer regulatory cells have also been shown to suppress allergen stimulated $\mathrm{T}$ cell proliferation in humans and may be important in tolerance induction as other regulatory cell types (102).

\section{Innate Lymphoid Cells and Allergen Immunotherapy}

The effect of allergen immunotherapy on innate lymphoid cells, ILC type 2, has been studied in grass pollen allergy in peripheral blood. AIT supressed seasonal increases in ILC2s in patients treated with immunotherapy compared to untreated controls (103). The decrease in ILC2s correlated with the self reported symptoms. Moreover, the proportion of IL-13+ ILC2s also decreased. In another study of seasonal asthmatic patients, Lombardi et al could not show any change in the number of ILC2s during immunotherapy which was explained by nonseasonal measurements while patients were asymptomatic (104). Up to date, there is no evidence that immunotherapy has any effect on epithelially derived cytokines, such as IL-25, IL-33, and TSLP which have regulatory effects on local type 2 inflammation and ILCs (54).

\section{Histamine and Histamine Receptors on VIT} During VIT an early desensitization develops within days or even hours depending on the type of immunotherapy protocol used, such as rush and ultrarush type of VIT. There is a decrease in basophil numbers, preformed mediators and mediator release by time $(75,105,106)$. Among four different type of histamine receptors histamine receptor type 2 (HR2) plays important roles with the peripheral antigen tolerance (89). Basophil supression starts by the activation of histamine type 2 receptors (HR2). H2R decreases allergen-induced FceRImediated basophil degranulation and mediator release (107). HR2 is mainly involved in tolerogenic immune responses. It is upregulated in Th2 cells and both suppress allergen stimulated T cell responses and increase IL-10 production in beekeepers (89)

TABLE 2 | Risk factors for relapse of severe systemic reactions after stopping VIT $(9,11,15,124-127)$.

\section{RISK FACTOR}

Honeybee VIT (9)

Higher risk compared to vespid VIT

Systemic adverse events during VIT $(125,128)$

Severe reaction prior to VIT??

A significant increase in risk of relapse

Contoversial but greater risk for severe systemic reactions when relapse

Mastocytosis/high serum tryptase??

Conflicting results but not seem to be an important risk factor. If there is severe initial systemic reaction may be considered as a risk factor

Angiotensin converting enzyme inhibitors??
Conflicting results. The risk of relapse may be overestimated because of the small sample size and highly selected patient groups

which induces the development of peripheral tolerance $(76,108$, 109). Histamin via HR2, induces IL-10 production by dendritic cells and Th2 cells (110); increases the suppressive effect of TGF-b on T cells (111) and decreases IL-4 and IL-13 production whicch are the main Th2 type cytokines (112).

\section{EFFICACY AND SAFETY OF VENOM IMMUNOTHERAPY}

The efficacy of VIT ranges from 77 to $84 \%$ for honeybee and from 91 to $96 \%$ for wasp venom (9-11). Some factors, such as higher amount of allergen transferred during each sting reaction, consistency of the honeybee sting, diversity of the sensitization pattern of honeybee venom are among the proposed factors which may explain the lower success rates related with the honeybee VIT (9). VIT was found to be effective even after the build up phase and in one study with honebee venom a success rate of $89 \%$ was reported with sting challenge 1 week after reaching maintenance dose (113).

Considering honeybee venom immunotherapy, usage of component resolved sensitization patterns may help to increase the treatment success. Some patients are sensitized

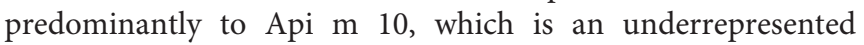
allergen in some VIT preparations that may cause a treatment failure $(114,115)$.

During the build-up phase of VIT, if SSR is a problem to reach the maintenance dose, premedication with omalizumab, an anti-IgE antibody, may be an option (116).

The dose of venom used during VIT is also important to prevent treatment failure. Usually a maintenance dose of $100 \mu \mathrm{g}$ venom during VIT is sufficient for protection (9). When the risk factors are high, as in beekeepers, a higher dose of venom gives

TABLE 3 | The methods used to monitor Venom immunotherapy (VIT) $(9,17,74,125,129)$.

\section{METHOD}

Sting challenge/Field sting

SlgE and lgG4

Intradermal skin prick testing

Basophil sensitivity

Enzyme-linked immunosorbent facilitated antigen binding
Sting challenge is the Gold Standard. If not possible field stings may be used. However, field stings are not standardized and some difficulties to identify the stinging insect type

slgE serum levels decreases and IgG4 levels increase during VIT. However, protection from systemic reactions continues, although IgG4 decreases after VIT is discontinued. Their levels and ratios are not reliable to predict individual protection

This method is not predictive as the negative skin prick test result can not exclude a relapse wih a serious systemic reaction

The dose at which half of the maximum basophil response occurs, was suggested to monitor VIT

Only case series studies are present. Inhibitor activity decreases after stopping VIT. Not possible to estimate the individual risk of relapse 
better results (117). If a systemic reaction develops following a field sting or sting challenge during a conventional dose of 100 $\mu \mathrm{g}$, a higher dose, $200 \mu \mathrm{g}$, is recommended (118).

Relapse rates up to $10 \%$ has been reported in 1-5 years after stopping of vespula VIT and more common in honeybee VIT (9). In one study a relapse rate of $7.5 \%$ for vespula VIT and $15.8 \%$ for honeybee VIT were reported 3-5 years after stopping VIT (17). In children, VIT shows a better prognosis compared to adults and only $5 \%$ of the children develop moderate to severe systemic reactions to stings up to 20 years of follow-up after discontinuing VIT (15).

Duration of the VIT is important for the efficacy. One year of treatment has failed in nearly one quarter of patients when they stung in 3-4 years after VIT (119). Studies of at least 5 years of treatment seem to show better protection compared to 3 years of treatment (120). Lerch et al showed lower systemic reaction rates in patients receiving VIT for $\geq 50$ months compared to those treated for 33-49 months (5 vs. 18\%, respectively) (17). In another study, Golden et al. evaluated patients treated with VIT for at least 5 years and found a systemic reaction rate of $9.5 \%$ within 5 years after discontinuing VIT (121).

A recent meta-analysis including five systematic reviews, five RCTs, three controlled (before and after) studies and four case series, showed that VIT significantly reduced the risk of severe systemic reactions $(\mathrm{OR}=0.08,95 \% \mathrm{CI} 0.03-0.26)$; improved quality of life (risk differenece: $1.41,95 \% \mathrm{CI} 1.04-1.79$ ) and may be cost effective in those who experienced repeated systemic reactions and impaired quality of life (122).

Adverse events are usually mild during VIT. Patients having systemic reactions develop relapse much more frequently compared to those who did not (16.4-38\% vs. 5.4-8\%) (11).

Some of the previous risk factors for systemic adverse events during VIT are no longer considered as important risk factors. These older risk factors include mastocytosis, ACE inhibitors, beta-blocker use, high specific IgE levels and skin prick test positivity at low test concerntrations (9). High basal tryptase levels in vespid allergy may be a risk factor for systemic adverse events in VIT (12) but not in honeybee venom allergy (123).

\section{REFERENCES}

1. Krishna MT, Ewan PW, Diwakar L, Durham SR, Frew AJ, Leech SC, et al. Diagnosis and management of hymenoptera venom allergy: British society for allergy and clinical immunology (BSACI) guidelines. Clin Exp Allergy. (2011) 41:1201-20. doi: 10.1111/j.1365-2222.2011.03788.x

2. Tan JW, Campbell DE. Insect allergy in children. J Paediatr Child Health. (2013) 49:E381-7. doi: 10.1111/jpc.12178

3. Hoffman DR, Jacobson RS. Allergens in hymenoptera venom XII: how much protein is in a sting? Ann Allergy. (1984) 52:276-8.

4. Ellis AK, Day JH. Clinical reactivity to insect stings. Curr Opin Allergy Clin Immunol. (2005) 5:349-54. doi: 10.1097/01.all.0000174159.55756.58

5. Mauriello PM, Barde SH, Georgitis JW, Reisman RE. Natural history of large local reactions from stinging insects. J Allergy Clin Immunol. (1984) 74(4 Pt 1):494-8. doi: 10.1016/0091-6749(84)90384-1

6. Ludman SW, Boyle RJ. Stinging insect allergy: current perspectives on venom immunotherapy. J Asthma Allergy. (2015) 8:75-86. doi: 10.2147/JAA.S62288

7. Bilo BM, Bonifazi F. Epidemiology of insect-venom anaphylaxis. Curr Opin Allergy Clin Immunol. (2008) 8:330-7. doi: 10.1097/ACI.0b013e32830638c5
Risk factors for relapse of SSR after stopping VIT are given in Table 2.

Currently, sting challenge is the gold standard to identify the efficacy of VIT and to differentiate the responders from non-responders. The methods used to monitor VIT are given in Table 3.

\section{CONCLUSION}

Insect venom allergy is one of the most common causes of anaphylaxis in humans and it is a medical emergency. Currently there is no biomarker to predict the risk of anaphylaxis. VIT is the most effective treatment for preventing SSR to a sting and decreases the risk of anaphylaxis. However, there are still some questions to be answered, such as cost of effectiveness, effect on quality of life, duration of treatment, optimal dose and means of assessment. Peripheral tolerance development is the main mechanism during VIT, which is orchestrated by $\mathrm{T}$ regulatory cells. T regs produce IL-10 and suppress Th2 immunity and the immune responses shift toward Th1 type inflammation. Blocking IgG1/IgG4 antibodies inhibit IgE dependent reactions on mast cells, basophils and B cells. Several other mechanisms, such as epithelial cells, several cytokines, dendritic cells, ILC2s and B regulatory cells are also involved in the development of long term immune tolerance.

Factors, such as increasing knowledge about risk factors for venom anaphylaxis, better patient education, developing more effective VIT products with less side effects, and finding effective biomarkers to predict future systemic reactions at the individual level, will significantly improve patient care.

\section{AUTHOR CONTRIBUTIONS}

US made the literature search, prepared the figure and tables, and wrote the article under the supervision of SD. SD planned the whole body of text, read the manuscript, made the necessary corrections, and detailed the discussion on the mechanisms of immunotherapy.

8. Jennings A, Duggan E, Perry IJ, Hourihane JO. Epidemiology of allergic reactions to hymenoptera stings in Irish school children. Pediatr Allergy Immunol. (2010) 21:1166-70. doi: 10.1111/j.1399-3038.2010.01054.x

9. Sturm GJ, Varga EM, Roberts G, Mosbech H, Bilo MB, Akdis CA, et al. EAACI guidelines on allergen immunotherapy: Hymenoptera venom allergy. Allergy. (2018) 73:744-64. doi: 10.1111/all.13262

10. Muller U, Helbling A, Berchtold E. Immunotherapy with honeybee venom and yellow jacket venom is different regarding efficacy and safety. $J$ Allergy Clin Immunol. (1992) 89:529-35. doi: 10.1016/0091-6749(92)90 319-W

11. Rueff F, Vos B, Oude Elberink J, Bender A, Chatelain R, Dugas-Breit S, et al. Predictors of clinical effectiveness of Hymenoptera venom immunotherapy. Clin Exp Allergy. (2014) 44:736-46. doi: 10.1111/cea.12275

12. Rueff F, Przybilla B, Bilo MB, Muller U, Scheipl F, Aberer W, et al. Predictors of side effects during the buildup phase of venom immunotherapy for Hymenoptera venom allergy: the importance of baseline serum tryptase. $J$ Allergy Clin Immunol. (2010) 126:105-11.e5. doi: 10.1016/j.jaci.2010.04.025

13. Mosbech H, Muller U. Side-effects of insect venom immunotherapy: results from an EAACI multicenter study. European Academy of 
Allergology and Clinical Immunology. Allergy. (2000) 55:1005-10. doi: $10.1034 / j .1398-9995.2000 .00587 . x$

14. Stoevesandt J, Hain J, Stolze I, Kerstan A, Trautmann A. Angiotensinconverting enzyme inhibitors do not impair the safety of Hymenoptera venom immunotherapy build-up phase. Clin Exp Allergy. (2014) 44:747-55. doi: 10.1111/cea.12276

15. Golden DB, Kagey-Sobotka A, Norman PS, Hamilton RG, Lichtenstein LM. Outcomes of allergy to insect stings in children, with and without venom immunotherapy. $N$ Engl J Med. (2004) 351:668-74. doi: 10.1056/NEJMoa022952

16. Reisman RE. Duration of venom immunotherapy: relationship to the severity of symptoms of initial insect sting anaphylaxis. J Allergy Clin Immunol. (1993) 92:831-6. doi: 10.1016/0091-6749(93)90060-S

17. Lerch E, Muller UR. Long-term protection after stopping venom immunotherapy: results of re-stings in 200 patients. J Allergy Clin Immunol. (1998) 101:606-12. doi: 10.1016/S0091-6749(98)70167-8

18. Novembre E, Cianferoni A, Bernardini R, Veltroni M, Ingargiola A, Lombardi E, et al. Epidemiology of insect venom sensitivity in children and its correlation to clinical and atopic features. Clin Exp Allergy. (1998) 28:834-8. doi: 10.1046/j.1365-2222.1998.00313.x

19. Grigoreas C, Galatas ID, Kiamouris C, Papaioannou D. Insect-venom allergy in Greek adults. Allergy. (1997) 52:51-7. doi: 10.1111/j.1398-9995.1997.tb02545.x

20. Incorvaia $\mathrm{C}$, Mauro $\mathrm{M}$, Pastorello EA. Hymenoptera stings in conscripts. Allergy. (1997) 52:680-1. doi: 10.1111/j.1398-9995.1997.tb01056.x

21. Fernandez J, Blanca M, Soriano V, Sanchez J, Juarez C. Epidemiological study of the prevalence of allergic reactions to Hymenoptera in a rural population in the Mediterranean area. Clin Exp Allergy. (1999) 29:1069-74. doi: 10.1046/j.1365-2222.1999.00614.x

22. Navarro LA, Pelaez A, de la Torre F, Tenias Burillo JM, Megias J, Martinez I. Epidemiological factors on hymenoptera venom allergy in a Spanish adult population. J Investig Allergol Clin Immunol. (2004) 14:134-41.

23. Fernandez J, Soriano V, Mayorga L, Mayor M. Natural history of Hymenoptera venom allergy in Eastern Spain. Clin Exp Allergy. (2005) 35:179-85. doi: 10.1111/j.1365-2222.2005.02169.x

24. Bilo MB, Cichocka-Jarosz E, Pumphrey R, Oude-Elberink JN, Lange J, Jakob $\mathrm{T}$, et al. Self-medication of anaphylactic reactions due to Hymenoptera stings-an EAACI task force consensus statement. Allergy. (2016) 71:931-43. doi: $10.1111 /$ all. 12908

25. Muller UR. Bee venom allergy in beekeepers and their family members. Curr Opin Allergy Clin Immunol. (2005) 5:343-7. doi: 10.1097/01.all.0000173783.42906.95

26. Richter AG, Nightingale P, Huissoon AP, Krishna MT. Risk factors for systemic reactions to bee venom in British beekeepers. Ann Allergy Asthma Immunol. (2011) 106:159-63. doi: 10.1016/j.anai.2010.11.005

27. Worm M, Moneret-Vautrin A, Scherer K, Lang R, Fernandez-Rivas M, Cardona V, et al. First European data from the network of severe allergic reactions (NORA). Allergy. (2014) 69:1397-404. doi: 10.1111/all.12475

28. Prado M, Quiros D, Lomonte B. Mortality due to Hymenoptera stings in Costa Rica, 1985-2006. Rev Panam Salud Publica. (2009) 25:389-93. doi: 10.1590/S1020-49892009000500002

29. Barnard JH. Studies of 400 Hymenoptera sting deaths in the United States. $J$ Allergy Clin Immunol. (1973) 52:259-64. doi: 10.1016/0091-6749(73)90044-4

30. Turner PJ, Gowland MH, Sharma V, Ierodiakonou D, Harper N, Garcez $\mathrm{T}$, et al. Increase in anaphylaxis-related hospitalizations but no increase in fatalities: an analysis of United Kingdom national anaphylaxis data, 1992-2012. J Allergy Clin Immunol. (2015) 135:956-63.e1. doi: 10.1016/j.jaci.2014.10.021

31. Bilo BM, Rueff F, Mosbech H, Bonifazi F, Oude-Elberink JN, EAACI Interest Group on Insect Venom Hypersensitivity. Diagnosis of Hymenoptera venom allergy. Allergy. (2005) 60:1339-49. doi: 10.1111/j.1398-9995.2005.0 0963.x

32. Clark S, Camargo CA Jr. Epidemiology of anaphylaxis. Immunol Allergy Clin North Am. (2007) 27:145-63. doi: 10.1016/j.iac.2007.03.002

33. Rueff F, Przybilla B, Bilo MB, Muller U, Scheipl F, Aberer W, et al. Predictors of severe systemic anaphylactic reactions in patients with Hymenoptera venom allergy: importance of baseline serum tryptase-a study of the European Academy of Allergology and Clinical Immunology Interest Group on Insect Venom Hypersensitivity. J Allergy Clin Immunol. (2009) 124:104754. doi: 10.1016/j.jaci.2009.08.027

34. Arzt L, Bokanovic D, Schwarz I, Schrautzer C, Massone C, Horn M, et al. Hymenoptera stings in the head region induce impressive, but not severe sting reactions. Allergy. (2016) 71:1632-4. doi: 10.1111/all.12967

35. Brockow K, Jofer C, Behrendt H, Ring J. Anaphylaxis in patients with mastocytosis: a study on history, clinical features and risk factors in 120 patients. Allergy. (2008) 63:226-32. doi: 10.1111/j.1398-9995.2007.01569.x

36. Castells MC, Hornick JL, Akin C. Anaphylaxis after hymenoptera sting: is it venom allergy, a clonal disorder, or both? J Allergy Clin Immunol Pract. (2015) 3:350-5. doi: 10.1016/j.jaip.2015.03.015

37. Bonadonna $\mathrm{P}$, Bonifacio M, Lombardo C, Zanotti R. Hymenoptera allergy and mast cell activation syndromes. Curr Allergy Asthma Rep. (2016) 16:5. doi: 10.1007/s11882-015-0582-5

38. Stoevesandt J, Hain J, Kerstan A, Trautmann A. Over- and underestimated parameters in severe Hymenoptera venom-induced anaphylaxis: cardiovascular medication and absence of urticaria/angioedema. J Allergy Clin Immunol. (2012) 130:698-704.e1. doi: 10.1016/j.jaci.2012.03.024

39. Mueller UR. Cardiovascular disease and anaphylaxis. Curr Opin Allergy Clin Immunol. (2007) 7:337-41. doi: 10.1097/ACI.0b013e328259c328

40. Valent P, Akin C, Escribano L, Fodinger M, Hartmann K, Brockow K, et al. Standards and standardization in mastocytosis: consensus statements on diagnostics, treatment recommendations and response criteria. Eur J Clin Invest. (2007) 37:435-53. doi: 10.1111/j.1365-2362.2007.01807.x

41. Castells M, Metcalfe DD, Escribano L. Diagnosis and treatment of cutaneous mastocytosis in children: practical recommendations. Am J Clin Dermatol. (2011) 12:259-70. doi: 10.2165/11588890-000000000-00000

42. Akin C, Valent P. Diagnostic criteria and classification of mastocytosis in 2014. Immunol Allergy Clin North Am. (2014) 34:207-18. doi: 10.1016/j.iac.2014.02.003

43. Bonadonna P, Perbellini O, Passalacqua G, Caruso B, Colarossi S, Dal Fior $\mathrm{D}$, et al. Clonal mast cell disorders in patients with systemic reactions to Hymenoptera stings and increased serum tryptase levels. J Allergy Clin Immunol. (2009) 123:680-6. doi: 10.1016/j.jaci.2008.11.018

44. Alfaya Arias T, Soriano Gomis V, Soto Mera T, Vega Castro A, Vega Gutierrez JM, Alonso Llamazares A, et al. Hymenoptera allergy committee of the: key issues in hymenoptera venom allergy: an update. J Investig Allergol Clin Immunol. (2017) 27:19-31. doi: 10.18176/jiaci.0123

45. Gonzalez de Olano D, de la Hoz Caballer B, Nunez Lopez R, Sanchez Munoz L, Cuevas Agustin M, Dieguez MC, et al. Prevalence of allergy and anaphylactic symptoms in 210 adult and pediatric patients with mastocytosis in Spain: a study of the Spanish network on mastocytosis (REMA). Clin Exp Allergy. (2007) 37:1547-55. doi: 10.1111/j.1365-2222.2007.02804.x

46. Alvarez-Twose I, Zanotti R, Gonzalez-de-Olano D, Bonadonna P, Vega A, Matito A, et al. Nonaggressive systemic mastocytosis (SM) without skin lesions associated with insect-induced anaphylaxis shows unique features versus other indolent SM. J Allergy Clin Immunol. (2014) 133:520-8. doi: 10.1016/j.jaci.2013.06.020

47. Alvarez-Twose I, Gonzalez de Olano D, Sanchez-Munoz L, Matito A, Esteban-Lopez MI, Vega A, et al. Clinical, biological, and molecular characteristics of clonal mast cell disorders presenting with systemic mast cell activation symptoms. J Allergy Clin Immunol. (2010) 125:1269-78.e2. doi: 10.1016/j.jaci.2010.02.019

48. Muller U, Helbling A, Bischof M. Predictive value of venom-specific IgE, IgG and $\mathrm{IgG}$ subclass antibodies in patients on immunotherapy with honey bee venom. Allergy. (1989) 44:412-8. doi: 10.1111/j.1398-9995.1989.tb04172.x

49. Kemeny DM, Lessof MH, Patel S, Youlten LJ, Williams A, Lambourn E. IgG and IgE antibodies after immunotherapy with bee and wasp venom. Int Arch Allergy Appl Immunol. (1989) 88:247-9. doi: 10.1159/000234799

50. Michils A, Baldassarre S, Ledent C, Mairesse M, Gossart B, Duchateau J. Early effect of ultrarush venom immunotherapy on the $\operatorname{IgG}$ antibody response. Allergy. (2000) 55:455-62. doi: 10.1034/j.1398-9995.2000.00412.x

51. Aalberse RC, Dieges PH, Knul-Bretlova V, Vooren P, Aalbers M, van Leeuwen J. IgG4 as a blocking antibody. Clin Rev Allergy. (1983) 1:289-302.

52. Wachholz PA, Soni NK, Till SJ, Durham SR. Inhibition of allergenIgE binding to $B$ cells by $\operatorname{IgG}$ antibodies after grass pollen immunotherapy. J Allergy Clin Immunol. (2003) 112:915-22. doi: $10.1016 / \mathrm{S} 0091-6749(03) 02022-0$ 
53. Oefner CM, Winkler A, Hess C, Lorenz AK, Holecska V, Huxdorf M, et al. Tolerance induction with $\mathrm{T}$ cell-dependent protein antigens induces regulatory sialylated IgGs. J Allergy Clin Immunol. (2012) 129:1647-55.e13. doi: 10.1016/j.jaci.2012.02.037

54. Shamji MH, Durham SR. Mechanisms of allergen immunotherapy for inhaled allergens and predictive biomarkers. J Allergy Clin Immunol. (2017) 140:1485-98. doi: 10.1016/j.jaci.2017.10.010

55. Rispens T, Ooijevaar-de Heer P, Bende O, Aalberse RC. Mechanism of immunoglobulin G4 Fab-arm exchange. J Am Chem Soc. (2011) 133:1030211. doi: 10.1021/ja203638y

56. Flicker S, Valenta R. Renaissance of the blocking antibody concept in type I allergy. Int Arch Allergy Immunol. (2003) 132:13-24. doi: 10.1159/0000 73260

57. van Neerven RJ, Wikborg T, Lund G, Jacobsen B, Brinch-Nielsen A, Arnved J, et al. Blocking antibodies induced by specific allergy vaccination prevent the activation of $\mathrm{CD} 4^{+} \mathrm{T}$ cells by inhibiting serum-IgE-facilitated allergen presentation. J Immunol. (1999) 163:2944-52.

58. Wurtzen PA, Lund G, Lund K, Arvidsson M, Rak S, Ipsen H. A double-blind placebo-controlled birch allergy vaccination study II: correlation between inhibition of IgE binding, histamine release and facilitated allergen presentation. Clin Exp Allergy. (2008) 38:1290-301. doi: 10.1111/j.1365-2222.2008.03020.x

59. Akdis M, Burgler S, Crameri R, Eiwegger T, Fujita H, Gomez E, et al. Interleukins, from 1 to 37 , and interferon-gamma: receptors, functions, and roles in diseases. J Allergy Clin Immunol. (2011) 127:701-21.e1-70. doi: 10.1016/j.jaci.2010.11.050

60. Meiler F, Klunker S, Zimmermann M, Akdis CA, Akdis M. Distinct regulation of IgE, IgG4 and IgA by T regulatory cells and toll-like receptors. Allergy. (2008) 63:1455-63. doi: 10.1111/j.1398-9995.2008.01774.x

61. Carballido JM, Carballido-Perrig N, Kagi MK, Meloen RH, Wuthrich $\mathrm{B}$, Heusser $\mathrm{CH}$, et al. $\mathrm{T}$ cell epitope specificity in human allergic and nonallergic subjects to bee venom phospholipase A2. J Immunol. (1993) 150(8 Pt 1):3582-91.

62. Martinez-Gomez JM, Johansen P, Erdmann I, Senti G, Crameri R, Kundig TM. Intralymphatic injections as a new administration route for allergenspecific immunotherapy. Int Arch Allergy Immunol. (2009) 150:59-65. doi: $10.1159 / 000210381$

63. von Garnier C, Astori M, Kettner A, Dufour N, Heusser C, Corradin G, et al. Allergen-derived long peptide immunotherapy down-regulates specific IgE response and protects from anaphylaxis. Eur J Immunol. (2000) 30:1638-45. doi: 10.1002/1521-4141(200006)30:6<1638::AID-IMMU1638>3.0.CO;2-R

64. James LK, Shamji MH, Walker SM, Wilson DR, Wachholz PA, Francis JN, et al. Long-term tolerance after allergen immunotherapy is accompanied by selective persistence of blocking antibodies. J Allergy Clin Immunol. (2011) 127:509-16.e1-5. doi: 10.1016/j.jaci.2010.12.1080

65. Varga EM, Francis JN, Zach MS, Klunker S, Aberer W, Durham SR. Time course of serum inhibitory activity for facilitated allergen-IgE binding during bee venom immunotherapy in children. Clin Exp Allergy. (2009) 39:1353-7. doi: 10.1111/j.1365-2222.2009.03303.x

66. Varga EM, Kausar F, Aberer W, Zach M, Eber E, Durham SR, et al. Tolerant beekeepers display venom-specific functional IgG4 antibodies in the absence of specific IgE. J Allergy Clin Immunol. (2013) 131:1419-21. doi: 10.1016/j.jaci.2012.08.037

67. Plewako H, Wosinska K, Arvidsson M, Bjorkander J, Skov PS, Hakansson L, et al. Basophil interleukin 4 and interleukin 13 production is suppressed during the early phase of rush immunotherapy. Int Arch Allergy Immunol. (2006) 141:346-53. doi: 10.1159/000095461

68. Dugas-Breit S, Przybilla B, Dugas M, Arnold A, Pfundstein G, Kuchenhoff $\mathrm{H}$, et al. Serum concentration of baseline mast cell tryptase: evidence for a decline during long-term immunotherapy for Hymenoptera venom allergy. Clin Exp Allergy. (2010) 40:643-9. doi: 10.1111/j.1365-2222.2009. 03436.x

69. Siegmund R, Vogelsang H, Machnik A, Herrmann D. Surface membrane antigen alteration on blood basophils in patients with Hymenoptera venom allergy under immunotherapy. J Allergy Clin Immunol. (2000) 106:1190-5. doi: $10.1067 /$ mai.2000.110928

70. Eberlein-Konig B, Ullmann S, Thomas P, Przybilla B. Tryptase and histamine release due to a sting challenge in bee venom allergic patients treated successfully or unsuccessfully with hyposensitization. Clin Exp Allergy. (1995) 25:704-12. doi: 10.1111/j.1365-2222.1995.tb00007.x

71. Sturm GJ, Bohm E, Trummer M, Weiglhofer I, Heinemann A, Aberer W. The CD63 basophil activation test in Hymenoptera venom allergy: a prospective study. Allergy. (2004) 59:1110-7. doi: 10.1111/j.1398-9995.2004.00400.x

72. Mikkelsen S, Bibby BM, Dolberg MK, Dahl R, Hoffmann HJ. Basophil sensitivity through CD63 or CD203c is a functional measure for specific immunotherapy. Clin Mol Allergy. (2010) 8:2. doi: 10.1186/1476-7961-8-2

73. Zitnik SE, Vesel T, Avcin T, Silar M, Kosnik M, Korosec P. Monitoring honeybee venom immunotherapy in children with the basophil activation test. Pediatr Allergy Immunol. (2012) 23:166-72. doi: 10.1111/j.1399-3038.2011.01233.x

74. Erzen R, Kosnik M, Silar M, Korosec P. Basophil response and the induction of a tolerance in venom immunotherapy: a long-term sting challenge study. Allergy. (2012) 67:822-30. doi: 10.1111/j.1398-9995.2012.02817.x

75. Nullens S, Sabato V, Faber M, Leysen J, Bridts CH, De Clerck LS, et al. Basophilic histamine content and release during venom immunotherapy: insights by flow cytometry. Cytometry B Clin Cytom. (2013) 84:173-8. doi: $10.1002 /$ cyto.b. 21084

76. Jutel M, Muller UR, Fricker M, Rihs S, Pichler WJ, Dahinden C. Influence of bee venom immunotherapy on degranulation and leukotriene generation in human blood basophils. Clin Exp Allergy. (1996) 26:1112-8. doi: 10.1046/j.1365-2222.1996.d01-259.x

77. Akoum H, Duez C, Vorng H, Fahy O, Wallaert B, Tonnel AB, et al. Early modifications of chemokine production and mRNA expression during rush venom immunotherapy. Cytokine. (1998) 10:706-12. doi: $10.1006 /$ cyto. 1998.0348

78. Bussmann C, Xia J, Allam JP, Maintz L, Bieber T, Novak N. Early markers for protective mechanisms during rush venom immunotherapy. Allergy. (2010) 65:1558-65. doi: 10.1111/j.1398-9995.2010.02430.x

79. Lesourd B, Paupe J, Thiollet M, Moulias R, Sainte-Laudy J, Scheinmann P. Hymenoptera venom immunotherapy. I. Induction of T cell-mediated immunity by honeybee venom immunotherapy: relationships with specific antibody responses. J Allergy Clin Immunol. (1989) 83:563-71. doi: 10.1016/0091-6749(89)90067-5

80. Mamessier E, Birnbaum J, Dupuy P, Vervloet D, Magnan A. Ultra-rush venom immunotherapy induces differential $\mathrm{T}$ cell activation and regulatory patterns according to the severity of allergy. Clin Exp Allergy. (2006) 36:70413. doi: 10.1111/j.1365-2222.2006.02487.x

81. Schuerwegh AJ, De Clerck LS, Bridts CH, Stevens WJ. Wasp venom immunotherapy induces a shift from IL-4-producing towards interferongamma-producing $\mathrm{CD}^{+}{ }^{+}$and $\mathrm{CD} 8^{+}$T lymphocytes. Clin Exp Allergy. (2001) 31:740-6. doi: 10.1046/j.1365-2222.2001.01066.x

82. Tilmant L, Dessaint JP, Tsicopoulos A, Tonnel AB, Capron A. Concomitant augmentation of $\mathrm{CD}^{+}{ }^{+} \mathrm{CD}_{4} 5 \mathrm{R}^{+}$suppressor/inducer subset and diminution of $\mathrm{CD}^{+} \mathrm{CDw} 29^{+}$helper/inducer subset during rush hyposensitization in hymenoptera venom allergy. Clin Exp Immunol. (1989) 76:13-8.

83. Shamji MH, Ljorring C, Francis JN, Calderon MA, Larche M, Kimber I, et al. Functional rather than immunoreactive levels of IgG4 correlate closely with clinical response to grass pollen immunotherapy. Allergy. (2012) 67:217-26. doi: 10.1111/j.1398-9995.2011.02745.x

84. Shamji MH, Ljorring C, Wurtzen PA. Predictive biomarkers of clinical efficacy of allergen-specific immunotherapy: how to proceed. Immunotherapy. (2013) 5:203-6. doi: 10.2217/imt.13.6

85. Bohle B, Kinaciyan T, Gerstmayr M, Radakovics A, Jahn-Schmid B, Ebner C. Sublingual immunotherapy induces IL-10-producing $\mathrm{T}$ regulatory cells, allergen-specific T-cell tolerance, and immune deviation. J Allergy Clin Immunol. (2007) 120:707-13. doi: 10.1016/j.jaci.2007.06.013

86. Jutel M, Akdis M, Blaser K, Akdis CA. Mechanisms of allergen specific immunotherapy-T-cell tolerance and more. Allergy. (2006) 61:796-807. doi: 10.1111/j.1398-9995.2006.01175.x

87. Chen W, Jin W, Hardegen N, Lei KJ, Li L, Marinos N, et al. Conversion of peripheral $\mathrm{CD} 4{ }^{+} \mathrm{CD} 25^{-}$naive $\mathrm{T}$ cells to $\mathrm{CD} 4{ }^{+} \mathrm{CD} 25^{+}$ regulatory $\mathrm{T}$ cells by TGF-beta induction of transcription factor Foxp3. J Exp Med. (2003) 198:1875-86. doi: 10.1084/jem.2003 0152

88. Klunker S, Chong MM, Mantel PY, Palomares O, Bassin C, Ziegler M, et al. Transcription factors RUNX1 and RUNX3 in the induction and suppressive 
function of Foxp $3^{+}$inducible regulatory T cells. J Exp Med. (2009) 206:270115. doi: 10.1084/jem.20090596

89. Meiler F, Zumkehr J, Klunker S, Ruckert B, Akdis CA, Akdis M. In vivo switch to IL-10-secreting $\mathrm{T}$ regulatory cells in high dose allergen exposure. J Exp Med. (2008) 205:2887-98. doi: 10.1084/jem.20080193

90. Fallarino F, Grohmann U. Using an ancient tool for igniting and propagating immune tolerance: IDO as an inducer and amplifier of regulatory T cell functions. Curr Med Chem. (2011) 18:2215-21. doi: 10.2174/092986711795656027

91. Akdis CA, Blesken T, Akdis M, Wuthrich B, Blaser K. Role of interleukin 10 in specific immunotherapy. J Clin Invest. (1998) 102:98-106. doi: $10.1172 /$ JCI2250

92. Botturi K, Vervloet D, Magnan A. T cells and allergens relationships: are they that specific? Clin Exp Allergy. (2007) 37:1121-3. doi: $10.1111 / j .1365-2222.2007 .02773 . x$

93. Radulovic S, Jacobson MR, Durham SR, Nouri-Aria KT. Grass pollen immunotherapy induces Foxp3-expressing $\mathrm{CD}^{+} \mathrm{CD}^{+} 5^{+}$cells in the nasal mucosa. J Allergy Clin Immunol. (2008) 121:1467-72, 1472 e1. doi: 10.1016/j.jaci.2008.03.013

94. Pereira-Santos MC, Baptista AP, Melo A, Alves RR, Soares RS, Pedro $\mathrm{E}$, et al. Expansion of circulating Foxp $\left.3^{+}\right) \mathrm{D} 25$ bright $\mathrm{CD} 4^{+} \mathrm{T}$ cells during specific venom immunotherapy. Clin Exp Allergy. (2008) 38:291-7. doi: 10.1111/j.1365-2222.2007.02887.x

95. Jutel M, Akdis M, Budak F, Aebischer-Casaulta C, Wrzyszcz M, Blaser K, et al. IL-10 and TGF-beta cooperate in the regulatory $\mathrm{T}$ cell response to mucosal allergens in normal immunity and specific immunotherapy. Eur J Immunol. (2003) 33:1205-14. doi: 10.1002/eji.200322919

96. Nasser SM, Ying S, Meng Q, Kay AB, Ewan PW. Interleukin10 levels increase in cutaneous biopsies of patients undergoing wasp venom immunotherapy. Eur J Immunol. (2001) 31:3704-13. doi: 10.1002/1521-4141(200112)31:12<3704::AID-IMMU3704>3.0.CO;2-3

97. Varricchi G, Harker J, Borriello F, Marone G, Durham SR, Shamji MH. T follicular helper (Th) cells in normal immune responses and in allergic disorders. Allergy. (2016) 71:1086-94. doi: 10.1111/all.12878

98. Sage PT, Sharpe AH. T follicular regulatory cells. Immunol Rev. (2016) 271:246-59. doi: 10.1111/imr.12411

99. Schulten V, Tripple V, Seumois G, Qian Y, Scheuermann RH, Fu Z, et al. Allergen-specific immunotherapy modulates the balance of circulating Tfh and Tfr cells. J Allergy Clin Immunol. (2018) 141:775-777.e6. doi: 10.1016/j.jaci.2017.04.032

100. van de Veen W, Stanic B, Yaman G, Wawrzyniak M, Sollner S, Akdis DG, et al. IgG4 production is confined to human IL-10-producing regulatory B cells that suppress antigen-specific immune responses. J Allergy Clin Immunol. (2013) 131:1204-12. doi: 10.1016/j.jaci.2013.01.014

101. Rosser EC, Mauri C. Regulatory B cells: origin, phenotype, and function. Immunity. (2015) 42:607-12. doi: 10.1016/j.immuni.2015.04.005

102. Deniz G, van de Veen W, Akdis M. Natural killer cells in patients with allergic diseases. J Allergy Clin Immunol. (2013) 132:527-35. doi: 10.1016/j.jaci.2013.07.030

103. Lao-Araya M, Steveling E, Scadding GW, Durham SR, Shamji MH. Seasonal increases in peripheral innate lymphoid type 2 cells are inhibited by subcutaneous grass pollen immunotherapy. J Allergy Clin Immunol. (2014) 134:1193-5.e4. doi: 10.1016/j.jaci.2014.07.029

104. Lombardi V, Beuraud C, Neukirch C, Moussu H, Morizur L, Horiot $S$, et al. Circulating innate lymphoid cells are differentially regulated in allergic and nonallergic subjects. J Allergy Clin Immunol. (2016) 138:305-8. doi: 10.1016/j.jaci.2015.12.1325

105. Novak N, Mete N, Bussmann C, Maintz L, Bieber T, Akdis M, et al. Early suppression of basophil activation during allergen-specific immunotherapy by histamine receptor 2. J Allergy Clin Immunol. (2012) 130:1153-8.e2. doi: 10.1016/j.jaci.2012.04.039

106. Maintz L, Bussmann C, Bieber T, Novak N. Contribution of histamine metabolism to tachyphylaxis during the buildup phase of rush immunotherapy. J Allergy Clin Immunol. (2009) 123:701-3. doi: 10.1016/j.jaci.2008.11.009

107. Cavkaytar O, Akdis CA, Akdis M. Modulation of immune responses by immunotherapy in allergic diseases. Curr Opin Pharmacol. (2014) 17:30-7. doi: $10.1016 /$ j.coph.2014.07.003
108. Akdis CA, Jutel M, Akdis M. Regulatory effects of histamine and histamine receptor expression in human allergic immune responses. Chem Immunol Allergy. (2008) 94:67-82. doi: 10.1159/000154858

109. Jutel M, Akdis M, Akdis CA. Histamine, histamine receptors and their role in immune pathology. Clin Exp Allergy. (2009) 39:1786-800. doi: $\quad 10.1111 /$ j.1365-2222.2009.03 374. $\mathrm{x}$

110. Mazzoni A, Young HA, Spitzer JH, Visintin A, Segal DM. Histamine regulates cytokine production in maturing dendritic cells, resulting in altered $\mathrm{T}$ cell polarization. J Clin Invest. (2001) 108:1865-73. doi: 10.1172/JCI200113930

111. Osna N, Elliott K, Khan MM. Regulation of interleukin-10 secretion by histamine in TH2 cells and splenocytes. Int Immunopharmacol. (2001) 1:85-96. doi: 10.1016/S0162-3109(00)00268-X

112. Jutel M, Watanabe T, Klunker S, Akdis M, Thomet OA, Malolepszy J, et al. Histamine regulates T-cell and antibody responses by differential expression of H1 and H2 receptors. Nature. (2001) 413:420-5. doi: 10.1038/350 96564

113. Goldberg A, Confino-Cohen R. Bee venom immunotherapy-how early is it effective? Allergy. (2010) 65:391-5. doi: 10.1111/j.1398-9995.2009. 02198.x

114. Frick M, Fischer J, Helbling A, Rueff F, Wieczorek D, Ollert M, et al. Predominant Api m 10 sensitization as risk factor for treatment failure in honey bee venom immunotherapy. J Allergy Clin Immunol. (2016) 138:166371.e9. doi: 10.1016/j.jaci.2016.04.024

115. Blank S, Seismann H, Michel Y, McIntyre M, Cifuentes L, Braren I, et al. Api $\mathrm{m} \mathrm{10}$, a genuine A. mellifera venom allergen, is clinically relevant but underrepresented in therapeutic extracts. Allergy. (2011) 66:1322-9. doi: 10.1111/j.1398-9995.2011.02667.x

116. Stretz E, Oppel EM, Rawer HC, Chatelain R, Mastnik S, Przybilla B, et al. Overcoming severe adverse reactions to venom immunotherapy using antiIgE antibodies in combination with a high maintenance dose. Clin Exp Allergy. (2017) 47:1631-9. doi: 10.1111/cea.12997

117. Bousquet J, Menardo JL, Velasquez G, Michel FB. Systemic reactions during maintenance immunotherapy with honey bee venom. Ann Allergy. (1988) 61:63-8.

118. Rueff F, Wenderoth A, Przybilla B. Patients still reacting to a sting challenge while receiving conventional Hymenoptera venom immunotherapy are protected by increased venom doses. J Allergy Clin Immunol. (2001) 108:1027-32. doi: 10.1067/mai.2001.119154

119. Golden DB, Johnson K, Addison BI, Valentine MD, Kagey-Sobotka A, Lichtenstein LM. Clinical and immunologic observations in patients who stop venom immunotherapy. J Allergy Clin Immunol. (1986) 77:435-42. doi: 10.1016/0091-6749(86)90177-6

120. Muller UR, Ring J. When can immunotherapy for insect sting allergy be stopped? J Allergy Clin Immunol Pract. (2015) 3:324-8. doi: 10.1016/j.jaip.2014.11.018

121. Golden DB, Kwiterovich KA, Kagey-Sobotka A, Valentine MD, Lichtenstein LM. Discontinuing venom immunotherapy: outcome after five years. J Allergy Clin Immunol. (1996) 97:579-87. doi: 10.1016/S0091-6749(96)70302-0

122. Dhami S, Zaman H, Varga EM, Sturm GJ, Muraro A, Akdis CA, et al. Allergen immunotherapy for insect venom allergy: a systematic review and meta-analysis. Allergy. (2017) 72:342-65. doi: 10.1111/all. 13077

123. Korosec P, Ziberna K, Silar M, Dezman M, Celesnik Smodis N, Rijavec $M$, et al. Immunological and clinical factors associated with adverse systemic reactions during the build-up phase of honeybee venom immunotherapy. Clin Exp Allergy. (2015) 45:1579-89. doi: 10.1111/cea. 12582

124. Golden DB. Long-term outcome after venom immunotherapy. Curr Opin Allergy Clin Immunol. (2010) 10:337-41. doi: 10.1097/ACI.0b013e32833bc0ba

125. Muller U, Berchtold E, Helbling A. Honeybee venom allergy: results of a sting challenge 1 year after stopping successful venom immunotherapy in 86 patients. J Allergy Clin Immunol. (1991) 87:702-9. doi: 10.1016/0091-6749(91)9 0392-2 
126. Rueff F, Przybilla B, Bilo MB, Muller U, Scheipl F, Seitz MJ, et al. Clinical effectiveness of hymenoptera venom immunotherapy: a prospective observational multicenter study of the European academy of allergology and clinical immunology interest group on insect venom hypersensitivity. PLoS ONE. (2013) 8:e63233. doi: 10.1371/journal.pone.0063233

127. Slade CA, Douglass JA. Changing practice: no need to stop ACE inhibition for venom immunotherapy. Clin Exp Allergy. (2014) 44:617-9. doi: 10.1111/cea.12295

128. Golden DB, Kwiterovich KA, Kagey-Sobotka A, Lichtenstein LM. Discontinuing venom immunotherapy: extended observations. J Allergy Clin Immunol. (1998) 101:298-305. doi: 10.1016/S0091-6749(98) 70239-8

129. Mobs C, Muller J, Rudzio A, Pickert J, Blank S, Jakob T, et al. Decline of Ves $\mathrm{v} 5$-specific blocking capacity in wasp venom-allergic patients after stopping allergen immunotherapy. Allergy. (2015) 70:715-9. doi: 10.1111/all.12606
Conflict of Interest Statement: SD reports grants from ALK, Denmark, personal fees from Anergis, Switzerland, personal fees from Biomay, Austria, personal fees from Allergy Therapeutics, UK, personal fees from ALK, Horsholm, Denmark, personal fees from Allergy Therapeutics, outside the submitted work.

The remaining author declares that the research was conducted in the absence of any commercial or financial relationships that could be construed as a potential conflict of interest.

Copyright $\odot 2019$ Sahiner and Durham. This is an open-access article distributed under the terms of the Creative Commons Attribution License (CC BY). The use, distribution or reproduction in other forums is permitted, provided the original author(s) and the copyright owner(s) are credited and that the original publication in this journal is cited, in accordance with accepted academic practice. No use, distribution or reproduction is permitted which does not comply with these terms. 